\title{
Expression of concern: Identification of volatile constituents released from IQOS heat-not-burn tobacco HeatSticks using a direct sampling method
}

Ilies BD, Moosakutty SP, Kharbatia NM, et al Identification of volatile constituents released from IQOS heat-not-burn tobacco HeatSticks using a direct sampling method. Tobacco Control. Published Online First:26 May 2020. doi:10.1136/tobaccocontrol-2019-055521

The paper, 'Identification of volatile constituents released from IQOS heat-not-burn tobacco HeatSticks using a direct sampling method' was published in Tobacco Control in May 2020 after undergoing peer review. After a Rapid Response was received calling attention to questionable citations in the Introduction which did not support the statements being made, the authors were invited to respond with corrections. We have posted this Expression of Concern until the authors revise the section and the paper undergoes additional peer review.

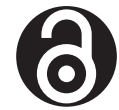

\section{OPEN ACCESS}

\begin{abstract}
Open access This is an open access article distributed in accordance with the Creative Commons Attribution Non Commercial (CC BY-NC 4.0) license, which permits others to distribute, remix, adapt, build upon this work noncommercially, and license their derivative works on different terms, provided the original work is properly cited, appropriate credit is given, any changes made indicated, and the use is non-commercial. See: http://creativecommons.org/licenses/by-nc/ 4.0\%.

(c) Author(s) (or their employer(s)) 2020. Re-use permitted under CC BY-NC. No commercial re-use. See rights and permissions. Published by BMJ.
\end{abstract}

Tob Control 2020;0:1. doi:10.1136/tobaccocontrol-2019-055521

A Check for updates 


\section{Retraction: Identification of volatile constituents released from IQOS heat-not- burn tobacco HeatSticks using a direct sampling method}

Ilies BD, Moosakutty SP, Kharbatia NM, et al. Identification of volatile constituents released from IQOS heat-not-burn tobacco HeatSticks using a direct sampling method. Tob Control Published Online First: 26 May 2020. doi: 10.1136/tobaccocontrol-2019-055521

This article has been retracted at the request of the authors after inaccuracies in the referencing and methodological issues were discovered.

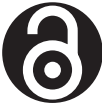

\section{OPEN ACCESS}

Open access This is an open access article distributed in accordance with the Creative Commons Attribution Non Commercial (CC BY-NC 4.0) license, which permits others to distribute, remix, adapt, build upon this work noncommercially, and license their derivative works on different terms, provided the original work is properly cited, appropriate credit is given, any changes made indicated, and the use is non-commercial. See: http://creativecommons.org/licenses/by-ncl 4.0\%.

(c) Author(s) (or their employer(s)) 2021. Re-use permitted under CC BY-NC. No commercial re-use. See rights and permissions. Published by BMJ.

Tob Control 2021;30:478. doi:10.1136/tobaccocontrol-2019-055521ret

D) Check for updates 